\title{
Kaderisasi Kepemimpinan Pesantren Terhadap Putra Kiyai Studi Kasus di Pondok Pesantren Al-Iman Bulus Purworejo
}

\author{
Nurul Hidayah
}

Pascasarjana IAINU Kebumen

Naskah diterima 28 April 2018, direvisi 19 Mei 2018, disetujui 10 Juli 2018

\begin{abstract}
Boarding school is the oldest Islamic institution in Indonesia since the 13th century and still exists to this day. Boarding schools have a major role not only in terms of education, but also in terms of political, social, and cultural. This research included in the types of qualitative research phenomenological approach. Research data retrieved from the data source through in-depth interviews and then analyzed with model data analysis Miles and Huberman that is implement data reduction, data display, and conclusion drawing/verification. Researchers tested the validity of research data by using the technique of triangulation of sources. The results showed, Sayyid Hasan do boarding against his leadership cadre recruitment by means of formal and informal. Formally, the leadership cadre recruitment is done with the opportunity to give his students to participate in structural leadership of boarding school, participate in an organization outside of the boarding school, studied outside of boarding school Al-Iman in accordance with the interests of their respective students, and actively participate in the sub boarding units. As for informally, the leadership cadre recruitment is done with the method of awarding of exemplary and advice. Example and advice given repeatedly, especially related to the particularity of the nature of the leadership owned Sayyid Hasan. The nature of leadership which is owned by the idiosyncrasies of Sayyid Hasan include, the physical condition and mental healthy and strong, open towards students, and open with the public.
\end{abstract}

Keywords: leadership cadre recruitment, boarding school, leader of religion (kiyai)

Abstrak Pesantren merupakan lembaga pendidikan Islam tertua di Indonesia sejak abad ke-13 dan masih eksis hingga sekarang. Pesantren memiliki peranan besar tidak hanya dalam segi 
pendidikan, namun juga dalam segi politik, sosial, dan budaya. Penelitian ini termasuk dalam jenis penelitian kualitatif dengan pendekatan fenomenologis. Data penelitian diperoleh dari sumber data melalui wawancara mendalam kemudian dianalisis dengan analisis data model Miles \& Huberman yaitu dengan melakukan aktifitas data reduction, data display, dan conclusiondrawing/ verification. Peneliti menguji keabsahan data penelitian dengan menggunakan teknik triangulasi sumber. Hasil penelitian menunjukkan, Sayyid Hasan melakukan kaderisasi kepemimpinan pesantren terhadap putra-putranya dengan cara formal dan informal. Secara formal, kaderisasi kepemimpinan dilakukan dengan memberi kesempatan kepada putra-putranya untuk berperan serta dalam struktural kepemimpinan pesantren, berpartisipasi dalam suatu organisasi di luar pesantren, menimba ilmu di luar pesantren Al-Iman sesuai dengan minat masing-masing putra, dan berpartisipasi aktif di dalam suatusub unit pesantren. Adapun secara informal, kaderisasi kepemimpinan dilakukan dengan metode pemberian teladan dan nasihat. Teladan dan nasihat diberikan secara berulang-ulang,terutama terkait kekhasan sifat kepemimpinan yang dimiliki Sayyid Hasan. Sifat kepemimpinan yang merupakan kekhasan yang dimiliki Sayyid Hasan diantaranya yaitu kondisi fisik dan jiwa yang sehat dan kuat, open terhadap santri, dan terbuka dengan masyarakat.

Kata kunci: Kaderisasi kepemimpinan, pesantren, kiyai

\section{A. PENDAHULUAN}

Pesantren merupakan lembaga pendidikan Islam tertua di Indonesia. Pesantren telah ada sejak abad ke-13 (Zamakhsyari Dofier, 2015: 61), dan masih eksis hingga sekarang. Sejak pesantren ada, pesantren telah memiliki peranan yang besar tidak hanya dalam segi pendidikan, namun juga dalam segi politik, sosial, dan budaya (Nurcholis Majid, 1997: 105). Peranan pesantren yang besar membuat pesantrenn dianggap sebagai aset bangsa sehingga pemerintah memberikan perhatian khusus dengan membentuk satu sub-direktorat khusus melalui Kementerian Agama yang bertugas mengurusi pesantren (Affandi Mochtar, 2009: 105). 
Sebagai aset bangsa, pesantren harus terus dijaga keberadaannya. Pesantren hingga saat ini terus mengalami perkembangan, baik dari segi kualitas maupun kuantitas. Berdasarkan data yang dihimpun oleh Kementerian Agama, melalui EMIS 2015/2016, diketahui bahwa seluruh pesantren di Indonesia berjumlah 28.984, dengan jumlah santri 4.290.626. Jumlah tersebut tentunya telah bertambah pada tahun 2018, meskipun belum ditemukan data terkait penambahan jumlah pesantren. Menurut Direktur Pendidikan Diniyah Dan Pondok Pesantren Kementerian Agama, Ahmad Zayadi pertumbuhan pesantren di Indonesia dianggap menakjubkan.

Sesuai dengan data Kementerian Agama, pada tahun 1977 jumlah pesantren hanya sekitar 4.195 buah dengan jumlah santri sekitar 677.394 orang. Jumlah ini mengalami peningkatan berarti pada tahun 1985, dimana pesantren berjumlah sekitar 6.239 buah dengan jumlah santri mencapai sekitar 1.08 .801 orang. Dua dasawarsa kemudian, 1997, Kementerian Agama mencatat jumlah pesantren sudah mengalami kenaikan 224 persen atau 9.388 buah, dan kenaikan jumlah santri mencapai 261 persen atau 1.770.768 orang. Kemudian pada tahun 2001,terdapat 11.312 pesantren dengan 2.737.805 santri. Pada tahun 2005 jumlah pesantren kembali meningkat menjadi 14.798 pesantren dengan santri berjumlah 3.464 .334 orang. Pada tahun 2016, terdapat 28.194 pesantren yang tersebar di wilayah kota maupun pedesaan dengan 4.290.626 santri, dan semuanya berstatus swasta.

Tahun demi tahun berganti, jumlah pesantren semakin meningkat. Meski demikian, tidak dapat dipungkiri bahwa dalam realitanya terdapat kasus pesantren yang mati dan meninggalkan sisa-sisanya ke dalam bentuk lembaga-lembaga pengajian. Beberapa contoh pesantren yang mengalami nasib tersebut yaitu pesantren Cempaka di Surabaya, pesantren Kademangan di Bangkalan, Madura, pesantren Maskumambang di Gresik, dan pesantren Jamsaren di Surakarta (Zamakshari Dofier, 2015: 59).

Selain itu, terdapat pula kasus pesantren yang tutup maupun alih fungsi. Berdasarkan data Litbang Kemenag Jawa Timur tahun 
2013, seperti yang dikutip oleh Thoyib, disebutkan bahwa banyak pesantren di Indonesia yang mengalami gulung tikar, baik pesantren modern maupun tradisional. Di Jawa Timur sendiri, dari jumlah keseluruhan sebanyak 3379 pesantren, pada tahun 20092013 terdapat 126 pesantren yang vakum bahkan beralih fungsi menjadi (M. Toyyib, 2014: 1).

Peristiwa senada juga terjadi di Kebumen, Jawa Tengah. Berita yang dihimpun oleh Sorot Kebumen tanggal delapan Juli 2018, menyebutkan bahwa berdasarkan data dari kantor Kementerian Agama Kebumen, jumlah pesantren di Kebumen saat ini hanya berjumlah tujuh puluh buah. Kondisi tersebut menunjukkan penurunan yang signifikan, karena pada tahun 2013 jumlah pondok pesantren di Kebumen masih sebanyak 179 buah yang tersebar di berbagai kecamatan.

Apabila dicermati secara mendalam, kasus yang terjadi terkait tutupnya pondok pesantren atau pesantren yang beralih fungsi, memiliki keterkaitan yang erat dengan kepemimpinan pengasuh pondok pesantren (kiai). Dhofier menyebutkan, pesantrenpesantren yang semula merupakan pesantren besar kemudian lama-kelamaan mati, disebabkan lemahnya kepemimpinan pesantren. Setelah kiainya yang masyhur meninggal dunia tanpa meninggalkan pengganti-pengganti yang memiliki kemampuan, baik dalam pengetahuan Islam maupun dalam kepemimpinan organisasi, pesantren yang masyhur pun ikut mati (Zamakshari Dofier, 2015: 59).

Kiai dan pesantren memiliki keterkaitan yang erat.Kondisi pesantren bergantung pada kondisi kiai sehingga ciri-ciri kualitatif dan kuantitatif pesantren dalam arti pesantren dapat tumbuh, berhenti, atau lenyap bergantung sepenuhnya pada kiai (Manfred Ziemek, 986: 109). Apabila kiai utama meninggal dan pesantren kekurangankader yang memadai maka lama-kelamaan pesantren pun mengalami penyusutan dan hampir punah. Namun demikian, pesantren dapat dikembangkan lagi oleh beberapa generasi setelahnya dengan menapak tilas pendiri utama. 
Salah satu contoh pesantren yang pernah mengalami fase mati/vakum, yaitu pesantren Al-Iman Purworejo. Bahkan pesantren Al-Iman pernah mengalami kevakuman sampai dua kali, yaitu pada tahun 1842 disebabkan meninggalnya Mbah Kiai Ngalim dan tahun 1938 disebabkan kepindahan Sayyid Dahlan ke Masjid Kauman Purworejo. Pada tahun 1950, pesantren Al-Iman dihidupkan kembali oleh adik Sayyid Dahlan, yaitu Sayyid Agil dan pesantren Al-Iman masih eksis hingga sekarang meski Sayyid Agil telah meninggal. Kepemimpinan pesantren saat ini berada di tangan putra Sayyid Agil, yaitu Sayyid Hasan.

Sayyid Hasan berhasil membawa pesantren Al-Iman pada fase kemajuan yang signifikan. Jika pada masa Sayyid Agil, pesantren Al-Iman hanya memiliki dua lembaga pendidikan, yaitu Madrasah Tsanawiyah dan Madrasah Aliyah dengan ratusan santri, maka pada saat ini pesantren Al-Iman telah melengkapi lembaga pendidikannya mulai dari jenjang pendidikan usia dini yaitu Roudotul Athfal dan Madrasah Ibtidaiyah hingga pendidikan tinggi yaitu Ma'had Aly dengan jumlah santri mencapai duaribu santri. Selain itu, perkembangan fisik pesantren juga mengalami kemajuan pesat. Pesantren dilengkapi dengan fasilitas asrama berlantai tiga, fasilitas MCK yang cukup memadai, fasilitas kantin, koperasi dan toko yang menyediakan berbagai kebutuhan seharihari santri, serta fasilitas yang menunjang life-skill santri seperti pertukangan, perikanan, dan peternakan.

Demi menjaga eksistensi pesantren Al-iman agar tidak terulang kembali masa kevakuman yang pernah terjadi sekaligus sebagai usaha peningkatan mutu pesantren maka diperlukan kaderisasi pesantren terhadap putra kia,yaitu Sayyid Hasan sebagai generasi yang paling berpeluang memimpin Pesantren Al-Iman pada masa yang akan datang. Alasan tersebutlah yang membuat penelitian terkait kaderisasi kepemimpinan di Pesantren Al-Iman perlu dilakukan. Penelitian ini akanmembahas usaha-usaha yang dilakukan Sayyid Hasan dalam kaderisasi kepemimpinan terhadap putra-putranya. 


\section{Kiai sebagai Tokoh Kunci dalam Kepemimpinan Pesantren}

Kiai merupakan elemen paling esensial dari suatu pesantren. Pertumbuhan pesantren bergantung sepenuhnya pada kemampuan pribadi kiai. Menurut asal-usulnya, kata kiai dipakai untuk tiga jenis gelar yang berbeda, yaitu: Gelar kehormatan untuk barang-barang yang dianggap keramat dalam budaya Jawa. Gelar kehormatan untuk orang-orang tua pada umumnya. Gelar yang diberikan oleh masyarakat kepada seorang ahli agamaIslam yang memiliki atau menjadi pemimpin pesantren dan mengajarkan kitab-kitab Islamklasik kepada para santrinya.

Menurut Ziemek, pengertian kiai dalam Indonesia modern adalah pendiri dan pemimpin sebuah pesantren, yang sebagai muslim terpelajar telah membaktikan hidupnya demi Allah serta menyebarluaskan dan memperdalam ajaran-ajaran serta pandangan Islam melalui kegiatan pendidikan. Dengan demikian, gelar kiaimerupakan pemuliaan dan pengakuan yang diberikan secara suka rela kepada ulama Islam pimpinan masyarakat setempat (Manfred Ziemek, 1986: 131). Gelar kiai yang demikianlah yang dimaksud dalam penelitian ini, yang secara sederhananya adalah pemimpin pesantren.

Kedudukan kiai dalam pesantren dapat diibaratkan sebagai raja dalam suatu kerajaan kecil. Kia merupakan sumber mutlak dari kekuasaan dan kewenangan dalam kehidupan di lingkungan pesantren. Tidak seorangpun yang dapat melawan kekuasaan kiai dalam lingkungan pesantrennya, kecuali kiai lain yang lebih besar pengaruhnya (Zamakhsyari, 2015; 94). Kiai memiliki otoritas dan wewenang yang mampu menentukan semua aspek kegiatan pendidikan dan kehidupan agama dalam pesantren atas tanggung jawabnya sendiri (Manfred Ziemek, 1986: 138). Dapat dikatakan bahwa kiai adalah pemimpin tertinggi dalam pesantren dengan kadar kekuasaan dan kewenangan yang tidak dimiliki oleh selainnya dan kekuasaan tersebut diakui serta dipatuhi oleh para santri sebagai anggota dalam masyarakat pesantren.

Kepemimpinan berasal dari kata pemimpin yang dalam bahasa Inggris disebut leader dari akar kata to lead mengandung makna 
bergerak lebih awal, berjalan di depan, mengambil langkah pertama, memelopori dan mengarahkan pikiran, pendapat, dan tindakan orang lain, serta membimbing, menuntun, dan menggerakkan orang lain melalui pengaruhnya. Pemimpin pesantren berarti orang yang bergerak paling awal dan menggerakkan orang lain yaitu santri, baik pikiran, pendapat, maupun tindakan dalam lingkungan pesantren.

Kepemimpinan dalam pesantren memiliki suatu keunikan yang tidak banyak dimiliki oleh lembaga lain, dan keunikan tersebut sah untuk dilakukan bahkan tidak memerlukan pertimbangan dari pihak lain. Keunikan yang dimaksud adalah pewarisan kepemimpinan dari kiai terhadap para putranya. Ziemek menyebutkan, seringkali kiai berusaha mewariskan kedudukannya sebagai pemimpin pesantren kepada putraputranya dengan mengarahkan pendidikan putra tersebut agar sang putra cakap dan bermotivasi untuk memimpin sebuah pesantren.

Putra kiai memiliki peluang yang besar dalam mewarisi sifat kepemimpinan orang tuanya. Meskipun tidak semua putra kiai terlahir secara alamiah dengan sifat kepemimpinan, namun pengasuhan, pendidikan serta keteladanan yang diberikan kiai sebagai pemimpin pesantren akan dapat membentuk karakter pemimpin pada diri sang putra. Interaksi sebagai anak dan ayah akan menjadi proses alamiah yang membentuk kepribadian pemimpin serta menjadi referensi dalam pemilihan sikap sebagai pemimpin. Peranan kiai sebagai orang tua dalam menyiapkan putra-putranya menjadi pemimpin pengganti pada masa yang akan datang merupakan usaha yang paling utama dalam kaderisasi kepemimpinan pesantren (A. Rohim Fakih dkk, 2001: 8).

\section{Pentingnya Kaderisasi Kepemimpinan Pesantren}

Setiap orang memiliki hak yang sama untuk menjadi seorang pemimpin, bahkan dalam suatu hadis disebutkan, 


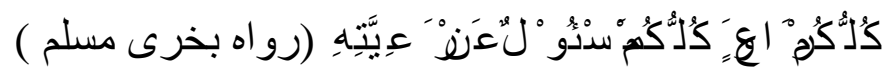

Artinya: Setiap kalian adalah pemimpin dan setiapkalianakan dimintai pertanggungjawaban atas kepemimpinannya (V.R. Zainal, M.D, 2017: 96).

Hadis ini menunjukkan bahwa pada dasarnya setiap manusia memiliki jiwa kepemimpinan, baik pada lingkup yang sempit maupun luas. Lingkup terkecil dalam kepemimpinan adalah memimpin diri sendiri, sedangkan lingkup yang besar dalam kepemimpinan adalah memimpin orang lain dengan jumlah yang banyak.

Tidak setiap orang pantas dan mampu menjadi pemimpin bagi orang lain, karena menjadi pemimpin tidaklah mudah. Terdapat kriteria-kriteria khusus yang harus dimiliki oleh seorang pemimpin, yang dengan kriteria-kriteria tersebut diharapkan seseorang dapat memimpin orang lain dengan baik dan mengarah kepada kebaikan. Namun demikian, setiap pemimpin harus memberikan kesempatan kepada orang-orang yang dipimpinnya untuk mendapatkan pengalaman memimpin. Kesempatan tersebut merupakan kegiatan yang berisi usaha-usaha yang mendukung bagi terbentuknya integritas kepribadian dan kemampuan menggerakkan orang lain secara intensif sehingga dapat mempersiapkannya untuk menjadi pemimpin pada masa yang akan datang. Pemberian kesempatan ini disebut dengan proses kaderisasi kepemimpinan.

Kaderisasi berasal dari kata kader. Kader dapat diartikan dengan orang yang diharapkan akan memegang peran kepemimpinan pada masa mendatang. Kaderisasi atau pengkaderan berarti proses, cara, perbuatan mendidik, atau membentuk seseorang menjadi kader (S. Falah, dkk). Natsir menekankan pentingnya kaderisasi. Menurutnya, seorang pemimpin harus sadar bahwa masa kepemimpinan yang dijalaninya pasti akan berakhir, posisinya akan digantikan oleh pemimpin baru, maka pada masa kepemimpinannya seorang pemimpin harus menyiapkan kader-kader untuk menggantikannya kelak (M. Natsir, 2008: 471).

Istilah kaderisasi, oleh Yukl disebut dengan kepemimpinan pendelegasian, yaitu sebuah proses yang terjadi bilapemimpin meminta seseorang atau beberapa orang bawahannya untuk 
mengambil alih tanggung jawab dalam membuat keputusan yang sebelumnya dibuat oleh pemimpin tersebut (Gary Yukl, 1998; 132). Kepemimpinan pendelegasianmemiliki beberapa manfaat, antara lain perbaikan kualitas keputusan, komitmen yang lebih besar dari bawahan dalam melaksanakan keputusan secara efektif, sebagai bentuk pengayaan tugas bagi bawahan yang menjadikan pekerjaan bawahan menjadi lebih menantang dan berarti.

Kaderisasi kepemimpinan perlu dilakukan karena suatu kepemimpinan pasti akan berakhir dengan sebab habisnya masa periode kepemimpinan atau pemimpin telah menjadi tua dan kehilangan kemampuan memimpin atau bahkan telah tutup usia. Kaderisasi kepemimpinan perlu diupayakan agar tersedia pemimpin dan calon pemimpin yang berkualitas sebagai pengganti pemimpin yang telah berakhir masa kepemimpinannya (V.R. Zainal, M.D, 2017: 96). Kondisi pesantren sebagai lembaga yang bergantung erat dengan kiai semakin menekankan perlunya kaderisasi kepemimpinan di dalamnya agar kasus pesantren mati/ vakum tidak perlu kembali terjadi di masa yang akan datang. Selain itu, usaha kaderisasi kepemimpinan akan menjadikan putra kiai sebagai pewaris kepemimpinan yang memiliki kecakapan dan motivasi yang tinggidalam memimpin pesantren.

Kiai memiliki fungsi sebagai seorang ulama, yaitu orang yang menguasai pengetahuan dalam tata masyarakat Islam dan menafsirkan peraturan-peraturan dalam hukum agama. Fungsi ini lebih memerlukan pengetahuan praktis di masyarakat dibanding pengetahuan secara teoretis. Lika-liku jalan pendidikan dan perkembangan seorang kiai berlangsung kebanyakan berada di luar jalur pendidikan formal dan berhubungan erat dengan keterampilan khusus yang diperlukan bagi kedudukannya yang terkemuka di lingkungan sosial. Hal ini menjadikan pesantren memiliki tugas mencetakpemimpin yang memiliki keterampilan khusus demi keberlangsungan pesantren. Dengan kata lain, kiai sebagai pemimpin pesantren harus melakukan kaderisasi kepemimpinan,karena hanya kiailah yang memahami kemampuan serta keterampilan apa saja yang diperlukan dalam memimpin pesantren.

\section{Model-Model Kaderisasi Kepemimpinan Pesantren}

Kaderisasi kepemimpinanpesantren oleh kiai terhadap putra kiai dapat dilakukan dengan dua model, yaitu formal dan informal. 
Kaderisasi formal-Kaderisasi formal merupakan usaha menyiapkan seseorang menjadi calon pemimpin dengan serangkaian cara yang dilakukan secara terencana, teratur, sistematis, terarah, dan disengaja. Kaderisasi formal dapat dilakukan dengan cara-cara sebagai berikut: Memberi kesempatan mendudukisuatu jabatan pemimpin pembantu. Memberikanlatihan kepemimpinan di dalam atau di luar organisasi. Memberikan tugas belajar untuk meningkatkan pengetahuan, wawasan, dan keterampilan kader. Memberi penugasan menjadi pemimpin pada suatu unit bagian organisasi.

Kaderisasi informal-Kaderisasi informal merupakan kebalikan dari kaderisasi formal.Dalam kaderisasi informal, cara-cara pengkaderan dilakukan dengan tidak terencana dan tidak sistematis, meskipun bisa dilakukan dengan sengaja. Kaderisasi informal dapat dilakukan dengan carapemberian teladan berupa akhlak dan kepribadian pemimpin oleh pemimpin terhadap para bawahan.Kaderisasi informal dilakukan oleh kiai terhadap putranya sepanjang waktu selama kiai masih hidup, karena segala sikap dan tingkah laku kiai merupakan teladan bagi para putranya.

\section{B. METODE PENELITIAN}

Penelitian ini termasuk dalam jenis penelitian lapangan dengan pendekatan kualitatif. Penelitian ini berupaya mengkaji tentang kualitas suatu kegiatan dengan menekankan pada penggambaran secara terperinci tentang hal-hal yang terjadi dalam kegiatan tersebut (Komaruddin Sastradipoera, 2005: 227). Kegiatan yang dimaksud yaitu proses kaderisasi kepemimpinan pesantren yang dilakukan oleh pengasuh Pesantren Al-Iman terhadap putraputranya. Pendekatan yang digunakan dalam penelitian ini adalah pendekatan fenomenologis. Pendekatan fenomenologis memungkinkan penelitian ini mereduksi pengalaman individu pada fenomena menjadi deskripsi tentang esensi atau intisari universal (John W. Creswell, 2015: 105). Pendekatan ini merupakan pendekatan yang tepat untuk mengetahui dan menganalisis model kaderisasi kepemimpinan pesantren yang dilakukan pengasuh Pesantren Al-Iman dengan memaknai berbagai kegiatan yang 
saling berkaitan dan berpengaruh di dalam proses kaderisasi tersebut.

Data penelitian diperoleh dari sumber data melalui wawancara mendalam (in dept interview) observasi dan studi dokumentasi. Data yang telah terkumpul, kemudian dianalisis dengan analisis data model Miles \& Huberman yaitu dengan melakukan aktifitas data reduction, data display, dan verification. Adapun langkahlangkah yang peneliti lakukan dalam menganalisis data adalah sebagai berikut (Sugiyono, 2017: 337): Peneliti menguji keabsahan data penelitian dengan menggunakan teknik triangulasi sumber, yaitu membandingkan dan mengecek derajat kepercayaan suatu informasi yang diperoleh melalui waktu dan alat yang berbeda dalam penelitian (Moleong \& Lexy J, 2017: 330). Penelitiakan melakukan triangulasi sumber dengan cara membandingkan suatu keadaan dan perspektif seseorang dengan berbagai pendapat dari beberapa sumber, dan membandingkan hasil wawancara dengan isi suatu dokumen yang berkaitan.

\section{HASIL DAN PEMBAHASAN}

\section{Pesantren Al-Iman Bulus Purworejo dari Masa ke Masa}

Pesantren Al-Iman Bulus Purworejo, merupakan pesantren tertua di Kabupaten Purworejo yang dulunya bernama Pesantren AlIslamiyah. Berdasarkan dokumen milik pesantren, disebutkan bahwa Pesantren Al-Iman telah berdiri sejak tahun 1828, yaitu pada masa perang Pangeran Diponegoro. Pendiri Pesantren AlIman adalah seorang yang terkenal 'alīm, dan merupakan ulama besar, yaitu Simbah Kyai Ahmad Ngalim. Pada masa itu Pesantren Al-Iman telah menjadi pusat pendidikan agama Islam yang dapat diperhitungkan mutunya. Banyak santri Pesantren Al-Iman yang kemudian menjadi ulama maupun umaro', seperti Simbah Kyai Sholih Darat Semarang.

Simbah Ahmad Ngalim wafat pada Jumat Wage tanggal satu JumadilAkhir tahun 1262 H/ 1842 M. Keterangan ini didasarkan data yang tertulis di nisan makam Mbah Ngalim yang terletak di belakang masjid Pesantren Al-Iman. Setelah sang kiai wafat, para 
santri pulang ke daerah asalnya masing-masing, sehingga Bulus pada waktu itu kosong hingga tiga tahun. Tanah pesantren diwakafkan kepada Sayyid Ali untuk meneruskan pesantren, sedangkan putra-putra Mbah Ahmad Ngalim diperintah untuk meninggalkan wilayah Bulus (hijrah). Putra-putra Mbah Ahmad Ngalim yang hijrah dari Bulus juga mendirikan pesantren, yakni Pesantren Maron, Pesantren Solotiyang dan Al-Anwar Purworejo.

Setelah Sayyid Ali wafat, kepemimpinan pesantren dilanjutkan oleh putranya yaitu Sayyid Muhammad (1913-1928 M). Pada masa itu Sayyid Muhammad menerapkan sistem pendidikan klasikal dengan mengajarkan sistem menulis Arab di papan tulis. Pendidikan klasikal tersebut merupakan lembaga pendidikan agama Islam pertama di Purworejo. Berdasarkan keterangan tersebut dapat diketahui bahwa sejak masa lampau, Pesantren AlIman telah menjadi basis pendidikan dengan sistem yang modern.

Pada periode berikutnya, perjuangan dilanjutkan oleh putra sulung Sayyid Muhammad yaitu Sayyid Dahlan. Pada masa Sayyid Dahlan, lembaga pendidikan pesantren diberi nama Madrasah alIslamiyyah. Sekitar tahun 1938 M, masjid Kauman Purworejo mengalami kevakuman imam masjid. Bupati Purworejo KRA. Hasan Danoediningrat menunjuk ulama dari Bulus untuk menjadi imam masjid Kauman Purworejo. Kepindahan Sayyid Dahlan tersebut, menjadikan pesantren mengalami kekosongan. Keadaan diperparah dengan adanya masa revolusi fisik menghadapi penjajahan (agresi militer) Belanda sehingga berimbas terhadap keberlangsungan pesantren karena ditinggalkan oleh kiai maupun santrinya untuk berjuang di medan tempur. Dimana-mana terjadi kekosongan kepemimpinan pesantren, tidak terkecuali pesantren Al-Islamiyah Bulus.

Setelah lama vakum dan tidak ada aktivitas, pesantren Bulus dibangun dan dihidupkan kembali oleh Sayyid Agil (adik Sayyid Dahlan) pada tahun 1955 M. Pesantren yang dulunya bernama AlIslamiyah diganti menjadi Al-Iman. Alasan digantinya Al-Islamiyah menjadi Al-Iman adalah untuk tafa'ulan (mengharap berkah) dengan nama pondok pesantren tempat ia menimba ilmu kepada 
Ustadz Sagaf Magelang. Pada masa Sayyid Agil, pelajaran-pelajaran umum mulai dimasukkan ke madrasah seperti bahasa Inggris dan bahasa Indonesia. Di samping mengembangkan pesantren, Sayyid Agil juga mengembangkan pendidikan formal dengan mendirikan Madrasah Tsanawiyah (MTs) dan Madrasah Aliyah (MA).

Sayyid Agil wafat pada tahun 1987 M, kepemimpinan pesantren kemudian dilanjutkan oleh putranya yang ketiga yaitu Sayyid Hasan (tahun 1987 sampai sekarang). Pada masa Sayyid Hasan Pesantren Al-Iman mengalami kemajuan yang pesat. Terbukti dengan jumlah santri yang terus bertambah, hingga kini mencapai jumlah lebih dari dua ribu santri, perkembangan pesantren secara fisik, serta perkembangan pendidikan formal yaitu pendirian Madrasah Ibtidaiyah (MI) Al-Iman, Raudhatul Athfal (RA) Al-Iman, dan Ma'had Aly.

Berdasarkan data-data terkait sejarah Pesantren Al-Iman, dapat diketahui bahwa sejak awal berdiri, pesantren Al-Iman telah menjadi basis pendidikan Islam khususnya di Kabupaten Purworejo. Bahkan ketika aktifitas belajar agama dengan papan tulis belum populer, Pesantren Al-Iman telah menerapkan aktifitas tersebut. Di pesantren, santri tidak hanya mempelajari ilmu-ilmu agama namun juga ilmu non agama seperti bahasa Indonesia dan bahasa Inggris. Hal ini menunjukkan bahwa para pemimpin pesantren Al-Iman merupakan pemimpin-pemimpin pesantren yang visioner dan terbuka dengan perkembangan zaman.

Sejak berdiri hingga saat ini, pesantren Al-Iman telah mengalami pergantian pemimpin sebanyak enam kali. Pemimpin Pesantren Al-Iman yang pertama sekaligus pendiri pesantren adalah Simbah Kiai Ahmad Ngalim yang memimpin pesantren dari tahun 1828 M sampai tahun 1842 M. Setelah Simbah Kiai Ahmad Ngalim wafat, pesantren mengalami kevakuman selama beberapa tahun dan kemudian pesantren dihidupkan oleh menantunya yaitu Sayyid Ali. Sayyid Ali memimpin pesantren hingga wafat yaitu pada tahun 1913 M, kemudian kepemimpinan pesantren diteruskan oleh putranya, yaitu Sayyid Muhammad, dari tahun 
1913 M. sampai tahun 1928M. Pada periode selanjutnya pesantren dipimpin oleh putra Sayyid Muhammad, yaitu Sayyid Dahlan sampai tahun 1938 M. Pada tahun tersebut Sayyid Dahlan pindah ke kompleks Masjid Kauman Purworejo atas permintaan Bupati sehingga pesantren Al-Iman mengalami masa kevakuman untuk yang kedua kali. Masa vakum berlangsung hingga tujuh belas tahun dikarenakan pada masa itu bertepatan dengan terjadinya agresi militer Belanda sehingga orang-orang dewasa dan para pemuda dikerahkan untuk berperang melawan Belanda.Pada tahun 1955 M. pesantren dihidupkan kembali oleh Sayyid Agil, yaitu adik dari Sayyid Dahlan.Sayyid Agil memimpin pesantren hingga wafat yaitu pada tahun 1987 M. kemudian kepemimpinan pesantren dilanjutkan oleh Sayyid Hasan hingga saat ini.

\section{Kepemimpinan Sayyid Hasan dan KaderisasiKepemimpinan terhadap Para Putra}

Berdasarkan data-data yang telah dikumpulkan dan diolah sesuai prosedur, maka penelitian terkait kaderisasi kepemimpinan pesantren terhadap putra kiai di Pesantren Al-Iman Bulus Purworejo menunjukkan hasil sebagai berikut:

Sayyid Hasan adalah putra ketiga dari Sayyid Agil yang memimpin pesantren Al-Iman sejak tahun 1987 M. sampai sekarang. Sayyid merupakan sebuah gelar yang dipakai untuk memanggil orang-orang yang memiliki silsilah keturunan sampai kepada Nabi Muhammad Saw. Sayyid terkadang disebut pula dengan gelar syarīf atau habīb. Ketiganya berasal dari Bahasa Arab. Sayyid berarti tuan, syarīf berarti yang mulia, sedangkan habīb berarti yang dikasihi atau dicintai. Masyarakat umum sering menyebut Sayyid Hasan dengan panggilan Habib Hasan atau Wan Hasan. Adapun para santri sering menyebut dengan panggilan Ustad. Di Pesantren Al-Iman panggilan Ustad hanya dipakai untuk menyebut atau memanggil Sayyid Hasan yang merupakan pemimpin pesantren.

Sayyid Hasan dikaruniai enam orang putra yaitu tiga laki-laki dan tiga perempuan. Putra pertama adalah seorang perempuan 
bernama Shofia Aqila (Pah Sofi), putra kedua dan ketiga adalah laki-laki dengan nama Abdurrahman (Wan Abid) dan Faqih Muqoddam (Wan Faqih). Putra keempat yaitu perempuan bernama Robiah Adawiyah (Pah Yaya), putra kelima yaitu laki-laki bernama Bahauddin Sosro Sumpeno (Wan Baha'), dan yang terakhir yaitu perempuan dengan nama Maryam Maharani (Pah Iyam). Semua putra laki-laki Sayyid Hasan memiliki gelar Habib dan putra perempuan memiliki gelar Syarifah. Para santri biasa memanggil putra Sayyid Hasan dengan sebutan Wan untuk putra laki-laki dan Pah/Ipah untuk putra perempuan. Sayyid Hasan melakukan kaderisasi kepemimpinan pesantren terhadap putraputranya dengan cara formal dan informal. Secara formal, upaya Sayyid Hasan dalam rangka kaderisasi kepemimpinan terhadap putra-putranya dilakukan dengan beberapa hal, yaitu:

Pertama memberi kesempatan kepada putra-putranya untuk berperan serta dalam struktural kepemimpinan pesantren. Pengalaman berperan serta dalam struktural kepemimpinan pesantren telah dirasakan oleh Pah Sofi, Wan Abid, dan Wan Faqih. Ketiganya telah cukup umur, yaitu Pah Sofi berumur 32 tahun, Wan Abid berumur 30 tahun, dan Wan Faqih berumur 28 tahun sehingga ketignya telah dewasa sertadipandang mampu menyumbangkan tenaga serta pikirannya dalam mengasuh pesantren. Selain itu ketiganya telah muqim (tinggal menetap) di rumah sehingga memudahkan para pengurus pesantren apabila ingin berkonsultasi terkait permasalahan-permasalahan yang sedang terjadi di pesantren. Secara struktural, Pah Sofi berperan sebagai pembimbing pesantren putri dengan jabatan di atas Lurah, Wan Abid dan Wan Faqih berperan sebagai dewan pertimbangan pesantren putra dengan jabatan di atas Lurah. Adapun Pah Yaya, Wan Baha' dan Pah Iyam belum ikut dalam struktural kepemimpinan dikarenakan usia yang masih muda, yaitu Pah Yaya berumur duapuluhtahun, Wan Baha' berumur 18 tahun, dan Pah Iyam berumur 13 tahun. Selain itu, ketiganya masih dalam posisi nyantri (belum muqim). 
Kedua Memberikan kesempatan untuk berpartisipasi dalam suatu organisasi di luar pesantren. Salah satu putra Sayyid Hasan yang aktif dalam organisasi di luar peantren adalah Wan Faqih. Kepribadian Wan Faqih yang supel membuatnya disukai banyak orang, sedangkan Wan Abid merupakan sosok pemalu yang cenderung tertutup sehingga tidak banyak berpartisipasi aktif dalam organisasi di luar pesantren meskipun tercatat sebagai anggota.Saat ini, Wan Faqih menjabat sebagai presiden Ballgiez (Bareng Lelampahan Generasi Penerus), yaitu sebuah organisasi yang beranggotakan para Gus (istilah yang umum digunakan untuk menyebut putra kiai) di wilayah eks karesidenan Kedu, dan menjadi pengurus MDS (Majelis Dzikir dan Shalawat) Rijalul Ansor Purworejo.

Ketiga Memberikan kesempatan menimba ilmu di luar pesantren Al-Iman sesuai dengan minat masing-masing putra. Putra-putra Sayyid Hasan memiliki pengalaman berbeda-beda dalam hal menimba ilmu. Pah Sofi menyelesaikan pendidikannya dari jenjang Sekolah Dasar, Madrasah Tsanawiyah, dan Madrasah Aliyah di desa Bulus. Setelah lulus Madrasah Aliyah, Pah Sofi melanjutkan pendidikannya dengan nyantri di pesantren Darullughah Wadda'wah Bangil, Pasuruan, Jawa Timur selama tujuh tahun.Wan Abid memiliki jalur pendidikan yang paling berbeda dari putra yang lain. Setelah menyelesaikan pendidikan Madrasah Aliyahnya di Al-Iman, Wan Abid memilih mempelajari ilmu non agama dengan melanjutkan pendidikannya ke perguruan tinggi yaitu Bina Sarana Informatika (BSI) kemudian dilanjutkan ke Universitas Teknologi Yogyakarta (UTY). Adapun Wan Faqih, setelah menyelesaikan pendidikan Madrasah Aliyahnya di AlIman, kemudian nyantri di pesantren Hidayatul Mubtadiin Lirboyo, Kediri, Jawa Timur. Jejak nyantri yang ditunjukkan Wan Faqih kemudian diikuti oleh ketiga adiknya. Pah Yaya berangkat nyantri ke pesantren Hidayatul Mubtadiat Lirboyo, Kediri, Jawa Timur setelah lulus dari Madrasah Tsanawiyah Al-Iman. Demikian juga dengan Wan Baha' yang nyantri di Lirboyo setelah lulus dari Madrasah Tsanawiyah Al-Iman. Adapun Pah Iyam berangkat 
nyantri ke pesantren Hidayatul Mubtadiat Lirboyo setelah lulus dari Sekolah Dasar Negeri bulus.

Keempat Memberikan kesempatan untuk berpartisipasi aktif di dalam suatu sub unit pesantren. Ketiga putra tertua Sayyid Hasan telah berpartisipasi aktif di dalam suatu sub unit pesntren AlIman. Sejak pulang dari nyantri, Pah Sofi tercatat sebagai pendidik di Madrasah Tsanawiyah (MTs) Al-Iman dan secara aktif mengampu mata pelajaran Bahasa Arab. Selain mendidik, Pah Sofi juga menjadi pimpinan pengelola koperasi pondok putri. Adapun pengelola hariannya adalah santri putri. Disebut dengan koperasi pondok putri dikarenakan lokasi koperasi yang berada di dalam komplek pesantren putri. Koperasi tersebut menjual berbagai makanan ringan, pakaian, sabun dan keperluan mandi lainnya.

Putra kedua Sayyid Hasan, yaitu Wan Abid memiliki aktifitas yang serupa dengan Pah Sofi. Kegiatan sehara-hari Wan Abid adalah mengajar kelas isti'dad. Kelas isti'dad adalah kelas persiapan untuk peserta didik MA Al-Iman yang berasal dari selain MTs Al-Iman. Kelas isti'dad berisi matrikulasi pelajaran-pelajaran pesantren untuk membekali peserta didik dalam mempelajari kitab kuning. Wan Abid juga merupakan pimpinan pengelola kantin putri. Kantin tersebut bertugas menyediakan makanan pokok sehari-hari untuk santri putri yang berupa nasi, sayur, dan lauk-pauk.Selain makanan pokok, kantin putri juga menyediakan bakso, soto, mi ayam, aneka gorengan, makanan ringan, dan berbagai minuman seperti kopi, teh, susu, dan jus. Dalam kesehariannya, kantin putri dikelola oleh beberapa santri putra yang telah lulus dari Madrasah Aliyah dan mengabdikan dirinya kepada keluarga Sayyid Hasan.

Adapun Wan Faqih, memiliki banyak kesibukan di luar pesantren. Wan Faqih merupakan putra andalan Sayyid Hasan. Wan Faqih sering diminta untuk menggantikan Sayyid Hasan yang berhalangan hadir menjadi pembicara dalam suatu undangan. Meskipun demikian, Wan Faqih tetap meluangkan waktu untuk mengajar santri dengan menjadi pendidik di Madrasah Aliyah AlIman dengan mengampu mata pelajaran tafsir jalalain. 
Keaktifan ketiga putra Sayyid Hasan di dalam sub unit pesantren membuat ketiganya lebih memahami kondisi pesantren secara riil, khususnya kondisi santri yang menjadi siswa MTs dan MA serta kondisi lingkungan belajar di MTs dan MA Al-Iman. Pemahaman yang baik terhadap kondisi pesantren secara riil memungkinkan ketiga putra Sayyid Hasan dapat mengambil keputusan yang bijaksana apabila terjadi suatu permasalahanpermasalahan di dalam pesantren Al-Iman.

Adapun secara informal, Sayyid Hasan melakukan upaya-upaya kaderisasi kepemimpinan terhadap putra-putranya dengan metode pemberian teladan dan nasihat. Teladan dan nasihat diberikan kepada putra-putranya secara berulangulang,terutamaterkait kekhasan sifat kepemimpinanyang dimiliki Sayyid Hasan. Sifat kepemimpinan yang merupakan kekhasan yang dimiliki Sayyid Hasan diantaranya yaitu fisik dan jiwa yang sehat dan kuat, open terhadap santri, dan terbuka dengan masyarakat. Sifat kekhasan tersebut dijelaskan secara rinci dalam paragraf sebagai berikut:

\section{Fisik dan jiwa yang sehat dan kuat}

Sayyid Hasan adalah salah seorang tokoh ulama di Kabupaten Purworejo.Selain memimpin pesantren, Sayyid Hasan merupakan mursyid tariqat Alawiyah dan Hadadiyah dengan jama'ah yang berasal dari berbagai kabupaten di Jawa Tengah, dan berbagai daerah di Indonesia. Saat ini Sayyid Hasan diberi amanah untuk menjadi Rois Syuriyah PCNU (Pengurus Cabang Nahdlatul 'Ulama) Kabupaten Purworejo. Mobilitas yang tinggi menuntut Sayyid Hasan memiliki fisik yang sehat, stamina yang kuat, dan vitalitas yang prima. Sayyid Hasan mencontohkan kepada putra-putranya untuk selalu menjaga asupan makanan yang masuk ke dalam tubuh. Halal dan toyyib merupakan syarat yang harus terpenuhi pada makanan. Selain itu, Sayyid Hasan mengkonsumsi buah pada setiap hari dan menghindari makanan yang dapat memicu munculnya penyakit. Menu favorit Sayyid Hasan adalah olahan daging ayam kampung.Menu ayam kampung merupakan menu 
yang terkenal enak dan sehat karena ayam kampung sendiri adalah ayam yang diberi pakan dari pakan alami bukan pakan instan. Hingga saat ini Sayyid Hasan tergolong memiliki fisik yang sehat. Hal ini terbukti, Sayyid Hasan tidak pernah mengalami sakit yang serius yang mengharuskan perawatan di rumah sakit. Di usianya yang telah menginjak angka enampuluh, Sayyid Hasan masih terlihat bugar dan gesit.

Selain fisik yang sehat, Sayyid Hasan juga menekankan perlunya mental dan jiwa yang kuat. Sebagai pemimpin pesantren, Sayyid Hasan hanya memiliki waktu tidur yang singkat yaitu tidak pernah lebih dari lima jam dalam satu hari. Waktu tidurnya adalah antara tengah malam setelah selesai mengampu sorogan santri hingga sepertiga malam terakhir dan pagi setelah mengampu ngaji bandongan santri pengurus dan takhasus hingga waktu duha.Sebagian besar waktu yang dimiliki, digunakan untuk melayani umat. Sayyid Hasan terkadang mengajak putranya untuk berdiskusi tentang berbagai hal pada malam hari hingga menjelang waktu subuh. Hal ini bertujuan melatih putra Sayyid Hasan untuk kuat melek wengiya itu terjaga pada malam hari untuk melakukan riyadah dengan qiyam al-lail (salat malam) dan mujahadah demi mendoakan para santri agar diberi futuh al-'ilmi (terbukanya hati dan pikiran untuk menerima ilmu) dan mendapatkan ilmu yang berkah dan manfaat.

\section{Open terhadap santri}

Sayyid Hasan sering berpesan kepada putranya untuk open terhadap santri (mengasuh santri dengan baik). Sikap open ini dicontohkan secara langsung oleh Sayyid Hasan dengan beberapa karakteristik yang khas. Dalam bidang pendidikan, Sayyid Hasan meluangkan waktu untuk membimbing santri secara langsung dalam mengaji pada setiap harinya. Tidak hanya dengan metode bandungan, tetapi juga dengan metode sorogan yang mana metode ini membutuhkan kesabaran dan ketelatenan yang lebih karena dilakukan dengan satu per satu atau face to face. Padahal santri yang mengikuti sorogan tersebut tidak hanya satu atau dua 
tetapi puluhan. Sorogan atau yang biasa disebut oleh santri dengan ngaji ndalem diadakan setiap malam selepas salat isya hingga tak ada lagi santri yang mengaji. Sering kali ngaji ndalem selesai pada pukul sebelas malam, namun apabila sedang banyak santri yang mengikuti, maka ngaji ndalem dapat berjalan hingga pukul dua belas malam. Adapun mengaji dengan metode bandungan dilakukan Sayyid Hasan pada pagi hari setelah subuh selama satu jam yang diikuti oleh para santri takhasus dan pengurus pesantren. Ngaji ndalem dan mengaji bakda subuh tersebut hanya diperuntukkan santri laki-laki. Santri perempuan dapat mengaji dengan bimbingan Sayyid Hasan pada pembelajaran kitab Tafsir Jalalain dan pengajian wetonan bulan ramadan.

Selain membimbing santri secara langsung dalam mengaji, Sayyid Hasan juga terus memotivasi para dewan guru dan orangorang yang secara langsung menangani pendidikan formal santri untuk selalu berupaya meningkatkan mutu pendidikan bagi santri. Hal ini membuahkan hasil pada nilai akreditasi madrasah. Pada tahun 2014, Madrasah Aliyah Al-Iman berhasil mendapatkan nilai A, yang kemudian disusul oleh Madrasah Tsanawiyah Al-Iman yang memperoleh nilai A pada akreditasi tahun 2017. Selain itu, MTs Al-Iman dalam tiga tahun terakhir secara berturut-turut menduduki ranking pertama dalam kategori nilai terbaik UAMBN (Ujian Akhir Madrasah Berstandar Nasional) se-kabupaten Purworejo.

Pada bidang yang lain, sikap open ditunjukkan Sayyid Hasan dengan usaha pembangunan fisik pesantren secara berkala. Bertambahnya jumlah santri tentunya berimbas pada bertambahnya kebutuhan asrama dan fasilitas lain yang menunjang santri untuk hidup di pesantren. Pembangunan terus dilakukan sepanjang tahun, baik pembangunan gedung asrama, madrasah, jalan setapak, maupun kamar mandi santri. Pesantren juga berupaya memberikan kenyamanan kepada santri dengan menyediakan fasilitas dapur, loundry, bank central Al-Iman sebagai perantara orang tua/ wali santri yang ingin mengirimkan 
uang kepada anaknya, kantin dengan berbagai menu makanan berat dan jajanan, serta toko dan koperasi yang menyediakan berbagai kebutuhan sehari-hari santri seperti kitab, buku dan alat tulis, sabun dan peralatan mandi, serta pakaian.

\section{Terbuka dengan masyarakat}

Sayyid Hasan merupakan seorang pemimpin yang terbuka dengan masyarakat. Sayyid Hasan dapat ditemui oleh siapa saja secara langsung di ndalem-nya (rumah) tanpa perlu mengadakan janji terlebih dahulu dan tanpa melalui perantara orang lain. Pintu ndalem hampir selalu terbuka pada setiap harinya kecuali telah larut malam. Sayyid Hasan tidak pernah membeda-bedakan tamu yang datang. Semua tamu disambut dengan baik dan ramah.Tamu rombongan dengan jumlah lebih dari sepuluh orang biasanya diterima di ruang tamu, sedangkan tamu individu atau tamu rombongan kecil yang terdiri dari dua, tiga atau empat orang diterima di ruang tengah ndalem.

Sayyid Hasan sering menekankan kepada putranya bahwa tamu adalah rahmat, maka setiap tamu yang datang harus disambut dengan baik. Selain itu, Sayyid Hasan juga menekankan bahwa semua manusia di mata Allah adalah sama, yang membedakan adalah ketaqwaannya, sedangkan taqwa adalah sikap hati dan tidak ada siapapun yang tahu hati seseorang kecuali Allah maka dari itu seyogyanya setiap manusia harus berbuat baik terhadap manusia lainnya tanpa perlu melihat tampilan lahirnya. Sikap ini dicontoh oleh putra-putranya dengan tidak memilihmilih dalam bergaul. Putra-putra Sayyid Hasan terbiasa bergaul dengan santri dalam kehidupan sehari-hari dan dapat bergaul dengan luwes dengan orang yang bukan santri. Bahkan Pah Yaya, pernah tinggal di asrama selama beberapa tahun. Artinya, Pah Yaya tidur, makan, belajar, dan melakukan berbagai aktifitas lain bersama santri dan seperti santri pada umumnya. Pengalaman senada juga dialami oleh Wan Faqih. Pada saat pertama kali datang ke pondok Hidayatul Mubtadiin Lirboyo untuk nyantri, Wan Faqih menyembunyikan identitas pribadinya agar dapat 
bergaul dengan santri lain dengan leluasa. Wan Faqih kawatir jika banyak santri yang mengetahui bahwa dirinya adalah seorang Habib dan orang tuanya adalah pengasuh pesantren, maka para santri akan merasa segan bergaul dengannya.

\section{KESIMPULAN}

Putra kiai memiliki peluang yang besar dalam mewarisi sifat kepemimpinan orang tuanya. Meskipun tidak semua putra kiai terlahir secara alamiah dengan sifat kepemimpinan, namun pengasuhan, pendidikan serta keteladanan yang diberikan kiai sebagai pemimpin pesantren akan dapat membentuk karakter pemimpin pada diri sang putra. Interaksi sebagai anak dan ayah akan menjadi proses alamiah yang membentuk kepribadian pemimpin serta menjadi referensi dalam pemilihan sikap sebagai pemimpin. Peranan kiai sebagai orang tua dalam menyiapkan putra-putranya menjadi pemimpin pengganti pada masa yang akan datang merupakan usaha yang paling utama dalam kaderisasi kepemimpinan pesantren. kaderisasi kepemimpinan pesantren dapat dilakukan dengan cara formal dan informal.

Secara formal, upaya Sayyid Hasan dalam rangka kaderisasi kepemimpinan terhadap putra-putranya dilakukan dengan beberapa hal, yaitu memberi kesempatan kepada putra-putranya untuk berperan serta dalam struktural kepemimpinan pesantren, berpartisipasi dalam suatu organisasi di luar pesantren, menimba ilmu di luar pesantren Al-Iman sesuai dengan minat masingmasing putra, dan berpartisipasi aktif di dalam suatu sub unit pesantren.

Adapun secara informal, Sayyid Hasan melakukan upaya-upaya kaderisasi kepemimpinan terhadap putra-putranya dengan metode pemberian teladan dan nasihat. Teladan dan nasihat diberikan kepada putra-putranya secara berulang-ulang, terutama terkait kekhasan sifat kepemimpinan yang dimiliki Sayyid Hasan. Sifat kepemimpinan yang merupakan kekhasan yang dimiliki Sayyid Hasan diantaranya yaitu fisik dan jiwa yang sehat dan kuat, open terhadap santri, dan terbuka dengan masyarakat. 


\section{DAFTAR PUSTAKA}

Creswell, J. W. 2015. Penelitian Kualitatif \& Desain Riset: Memilih

Diantara Lima Pendekatan, Terj. Ahmad Lintang Lazuardi, Yogyakarta: Pustaka Pelajar.

Dhofier, Zamakhsyari. 2015. Tradisi Pesantren: Studi Pandangan Hidup Kyai dan Visinya Mengenai Masa Depan Indonesia, Cet. IX, Jakarta: LP3S

Efendi, N. 2015. Islamic Educational Leadership: Memahami Integrasi

Konsep Kepemimpinan di Lembaga Pendidikan Islam, Yogyakarta:

Kalimedia.

Fakih, A. R dan Iip, W. 2001. Kepemimpinan Islam, Yogyakarta: UII Press.

Falah, S. dkk. 2016. Model Regenerasi dan Kaderisasi Kepemimpinan Dalam Islam, dalam jurnal EDUKA: Jurnal Pendidikan, Hukum, dan Bisnis. 2 (2):

Madjid, N. 1997. ,Bilik-Bilik Pesantren, Jakarta: Paramadina.

Mochtar, A. 2009. Kitab Kuning \& Tradisi Akademik Pesantren, Bekasi: Pustaka Isfahan.

Moleong, L. J. 2017. Metodologi Penelitian Kualitatif, Cet. XXXVI, Bandung: PT Remaja Rosdakarya.

Sastradipoera, K. 2005. Mencari Makna di Balik Penulisan Skripsi, Tesis, dan Disertasi, Bandung: Kappa-Sigma.

Thoyib, M. 2014. Model Manajemen Mutu Pembelajaran Entrepreneurship Berbasis Sistem Nilai, dalam jurnal Kodifikasia 8 (1):

Yukl, G. 1998. Kepemimpinan dalam Organisasi, Terj. Juyuf Udaya, Jakarta: Prenhalindo

Zainal, V.R., M.D. Hadad, dan M. Ramly. 2017. Kepemimpinan dan Perilaku Organisasi, Cet. XII, Depok: Rajagrafindo Persada.

Ziemek,M. 1986. Pesantren dalam Perubahan Sosial, Terj. Burche B. Soendjojo, Jakarta: P3M 